\title{
Game theoretic analysis of supply chain based on mean-variance approach under cap-and-trade policy
}

\author{
He, L.F. ${ }^{a}$, Zhang, X. ${ }^{a,}{ }^{*}$, Wang, Q.P. ${ }^{\text {b, }}{ }^{*}$, Hu, C.L. ${ }^{c,}$ \\ ${ }^{a}$ College of Management and Economics, Tianjin University, Tianjin, P.R. China \\ ${ }^{b}$ School of Management Science and Engineering, Hebei University of Economics and Business, Shijiazhuang, P.R. China \\ ${ }^{c}$ College of Intelligent Manufacturing, Tianjin Sino-German University of Applied Sciences, Tianjin, P.R. China
}

\begin{abstract}
A B S T R A C T
In recent years, carbon emission problem occurred by carbon dioxide as one of the main greenhouse gases, has become the focus due to its great influence on human life. With the increase of consumers' low-carbon consciousness, this paper studies the supply chain which consists of a single supplier and a single manufacturer in presence of market low-carbon preference. First, we establish the mean-variance analysis model. Second, we study the optimal decisions of channel members considering the risk factor in three situations: traditional supply chain without emission reduction, individual emission reduction by manufacturer and supply chain collaborative emission reduction. Finally, the equilibrium results are demonstrated by numerical studies. The results show that chain members' profits are not only affected by their own risk-aversion level, but also by other chain member's risk aversion level. More important is that there exist the optimal carbon emission reduction level and profits in system collaborative emission reduction. The research makes operation mechanism of low-carbon supply chain clearer and provides a theoretical reference for supply chain members on pricing and investment strategy of emission reduction.
\end{abstract}

(C) 2018 CPE, University of Maribor. All rights reserved.

\section{ARTICLE INFO}

Keywords:

Supply chain;

Cap-and-trade policy;

Carbon emission;

Game theoretic analysis;

Mean-variance model

*Corresponding authors:

feigemse@gmail.com

(Zhang, X.)

qinpeng@heuet.edu.cn

(Wang, Q.P.)

chenglinhu8@gmail.com

(Hu, C.L.)

Article history:

Received 21 January 2018

Revised 25 August 2018

Accepted 7 September 2018

\section{Reference}

[1] Dinan, T. (2008). Policy options for reducing $\mathrm{CO}_{2}$ emissions, Washington, D.C., The Congress of the United States, Congressional Budget Office.

[2] Yin, Z., Zhang, X. (2014). A review of the research on low carbon supply chain in the context of open economy, Inquiry Into Economic Issues, Vol. 9, 154-159, doi: 10.3969/j.issn.1006-2912.2014.09.025.

[3] Chen, J. (2012). Study on supply chain management in a low-carbon era, Journal of Systems \& Management, Vol. 21, Vol. 6, 721-728, doi: 10.3969/j.issn.1005-2542.2012.06.002.

[4] Wang, L., Zheng, Y., Gao, Y. (2014). Study on multi stage carbon footprint optimization of manufacturing supply chain, Journal of the Party School of the Central Committee of the C.P.C., Vol. 18, No. 4, 92-97, doi: 10.14119/j.cnki. zgxb.2014.04.057.

[5] Yang, C., Li, X., Shao, J. (2013). Optimization of carbon footprint of reverse supply chain in complex uncertain environment, Low-carbon Economy, Vol. 4, doi: 10.13529/j.cnki.enterprise.economy.2013.04.007.

[6] Wang, W.-B., Deng, W.-W., Bai, T., Da, Q.-L., Nie, R. (2016). Design the reward-penalty mechanism for reverse supply chains based on manufacturers' competition and carbon footprint constraints, Journal of Industrial Engineering and Engineering Management, Vol. 30, No. 2, 188-194, doi: 10.13587/i.cnki.jieem.2016.02.023.

[7] Nie, J.-J., Wang, T., Zhao, Y.-X., Zahng, L.-N. (2015). Collecting strategies for the closed-loop supply chain with remanufacturing in the constraint of carbon emission, Journal of Industrial Engineering and Engineering Management, Vol. 29, No. 3, 249-256, doi: 10.13587/j.cnki.jieem.2015.03.028. 
[8] Zhao, D.-Z., Yuan, B.-Y., Xia, L.-J., Xie, X.-P. (2014). Dynamic game study in supply chain with manufacturers' competition under the constraint of productions' emission, Industrial Engineering \& Management, Vol. 1, No. 8, 65-71, doi: 10.3969/j.issn.1007-5429.2014.01.011.

[9] Cholette, S., Venkat, K. (2009). The energy and carbon intensity of wine distribution: A study of logistical options for delivering wine to consumers, Journal of Cleaner Production, Vol. 17, No. 16, 1401-1413, doi: 10.1016/j. jclepro.2009.05.011.

[10] Du, S., Ma, F., Fu, Z., Zhu, L., Zhang, J. (2011). Game-theoretic analysis for an emission-dependent supply chain in a 'cap-and-trade'system, Annals of Operations Research, Vol. 228, No. 1, 135-149, doi: 10.1007/s10479-0110964-6.

[11] Das, C., Jharkharia, S. (2018). Low carbon supply chain: A state-of-the-art literature review, Journal of Manufacturing Technology Management, Vol. 29, No. 2, 398-428, doi: 10.1108/JMTM-09-2017-0188.

[12] Chen, F., Federgruen, A. (2000). Mean-variance analysis of basic inventory models, Working Paper, Columbia Business School, New York, USA.

[13] Wu, J., Li, J., Wang, S., Cheng, T.C.E. (2008). Mean-variance analysis of the newsvendor model with stockout cost, Omega, Vol. 37, No. 3, 724-730, doi: 10.1016/i.omega.2008.02.005.

[14] Ray, P., Jenamani, M. (2016). Mean-variance analysis of sourcing decision under disruption risk, European Journal of Operational Research, Vol. 250, No. 2, 679-689, doi: 10.1016/i.ejor.2015.09.028.

[15] Choi, T.-M., Li, D., Yan, H. (2008). Mean-variance analysis of a single supplier and retailer supply chain under a returns policy, European Journal of Operational Research, Vol. 184, No. 1, 356-376, doi: 10.1016/i.ejor.2006. $\underline{10.051}$.

[16] Yamaguchi, S., Goto, H., Kusukawa, E. (2017). Mean-variance analysis for optimal operation and supply chain coordination in a green supply chain, Industrial Engineeering \& Management Systems, Vol. 16, No. 1, 22-43, doi: 10.7232/iems.2017.16.1.022.

[17] Zhuo, W., Shao, L., Yang, H. (2018). Mean-variance analysis of option contracts in a two-echelon supply chain, European Journal of Operational Research, Vol. 271, No. 2, 535-547, doi: 10.1016/i.ejor.2018.05.033.

[18] Chiu, C.-H., Choi, T.-M. (2016). Supply chain risk analysis with mean-variance models: A technical review, Annals of Operations Research, Vol. 240, No. 2, 489-507, doi: 10.1007/s10479-013-1386-4.

[19] Zhang, J.-J., Nie, T.-F., Du, S.-F. (2011). Optimal emission-dependent production policy with stochastic demand, International Journal of Society Systems Science, Vol. 3, No. 1-2, 21-39, doi: 10.1504/IJSSS.2011.038931.

[20] Du, S., Ma, F., Fu, Z., Zhu, L., Zhang, J. (2011). Game-theoretic analysis for an emission-dependent supply chain in a 'cap-and-trade' system, Annals of Operations Research, Vol. 228, No. 1, 135-149, doi: 10.1007/s10479-0110964-6.

[21] Du, S., Zhu, L., Liang, L., Ma, F. (2013). Emission-dependent supply chain and environment-policy-making in the 'cap-and-trade' system, Energy Policy, Vol. 57, 61-67, doi: 10.1016/i.enpol.2012.09.042.

[22] $\mathrm{Du}, \mathrm{S} ., \mathrm{Hu}, \mathrm{L} .$, Song, M. (2014). Production optimization considering environmental performance and preference in the cap-and-trade system, Journal of Cleaner Production, Vol. 112, Part 2, 1600-1607, doi: 10.1016/i.jclepro. 2014.08.086.

[23] Zhao, D., Wang, B., Xu, C. (2014). Study on the coordination mechanism of supply chain considering the restriction of product carbon emissions, FORECAST, Vol. 33, No. 5, 76-80.

[24] Yuan, J., Ma, J., Yang, W. (2016). Revenue-sharing contract for supply chain under a cap and trade system, In: Proceedings of 2016 International Conference on Logistics, Informatics and Service Sciences (LISS), Sydney, Australia, 1-6, doi: 10.1109/LISS.2016.7854442.

[25] Lee, J., Lee, M.L., Park, M. (2018). A newsboy model with quick response under sustainable carbon cap-n-trade, Sustainability, Vol. 10, No. 5, doi: 10.3390/su10051410.

[26] Ma, C., Liu, X., Zhang, H., Wu, Y. (2016). A green production strategies for carbon-sensitive products with a carbon cap policy, Advances in Production Engineering \& Management, Vol. 11, No. 3, 216-226, doi: 10.14743/ apem2016.3.222.

[27] Wang, Q., He, L. (2018). Managing risk aversion for low-carbon supply chains with emission abatement outsourcing, International Journal of Environmental Research and Public Health, Vol. 15, No. 2, 367-387, doi: 10.3390/ijerph15020367.

[28] Zhang, J. (2016). The game analysis of low carbon supply chain collaboration in emission reduction research and development, Master thesis, Hunan University, Changsha, Hunan Province, China.

[29] He, L., Zhao, D., Xia, L. (2015). Game theoretic analysis of carbon emission abatement in fashion supply chains considering vertical incentives and channel structures, Sustainability, Vol. 7, No. 4, 4280-4309, doi: 10.3390/ su7044280.

[30] He, L., Hu, C., Zhao, D., Lu, H., Fu, X., Li, Y. (2016). Carbon emission mitigation through regulatory policies and operations adaptation in supply chains: Theoretic developments and extensions, Natural Hazards, Vol. 84, Supplement 1, 179-207, doi: 10.1007/s11069-016-2273-5.

[31] Abdallah, T., Farhat, A., Diabat, A., Kennedy, S. (2012). Green supply chains with carbon trading and environmental sourcing: Formulation and life cycle assessment, Applied Mathematical Modelling, Vol. 36, No. 9, 4271-4285, doi: 10.1016/j.apm.2011.11.056.

[32] Raz, G., Druehl, C.T., Blass, V. (2013). Design for the environment: Life-cycle approach using a newsvendor model, Production and Operations Management, Vol. 22, No. 4, 940-957, doi: 10.1111/poms.12011. 
APEM
Advances in Production Engineering \& Management Letnik 13 | Številka 3 | September 2018 | Strani 333-344 https://doi.org/10.14743/apem2018.3.294
ISSN 1854-6250

Spletna stran: apem-journal.org Izvirni znanstveni članek

\title{
Analiza dobavne verige s pomočjo teorije iger, temelječa na pristopu srednje variance ob upoštevanju politike trgovanja $z$ emisijami
}

\author{
He, L.F. ${ }^{a}$, Zhang, X. ${ }^{\mathrm{a},{ }^{*}}$, Wang, Q.P. ${ }^{\mathrm{b},{ }^{*}}$, Hu, C.L. ${ }^{\mathrm{c},}$ \\ ${ }^{a}$ College of Management and Economics, Tianjin University, Tianjin, P.R. China \\ ${ }^{\mathrm{b}}$ School of Management Science and Engineering, Hebei University of Economics and Business, Shijiazhuang, P.R. China

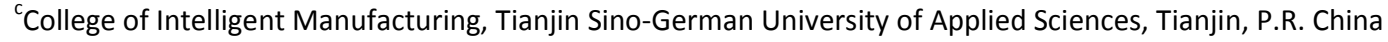

\section{POVZETEK}

V zadnjih letih so emisije ogljika vse pomembnejša tema, predvsem zaradi ogljikovega dioksida, ki je eden izmed glavnih toplogrednih plinov in ima velik vpliv na človekovo življenje. Ta članek preučuje oskrbovalno verigo, v okolju povečane okoljevarstvene zavesti potrošnikov, ki jo sestavljata en dobavitelj in en proizvajalec. Najprej je bil vzpostavljen model po načelu srednje variance. Nato so bile proučene optimalne odločitve članov verige glede na dejavnike tveganja $v$ treh primerih: tradicionalna dobavna veriga brez zmanjšanja emisij, zmanjšanje emisij proizvajalca in skupno zmanjšane emisij v dobavni verigi. Na koncu so rezultati prikazani z računsko študijo. Rezultati so pokazali, da dobiček članov verige ni odvisen le od njihove naklonjenosti tveganju, temveč tudi od naklonjenosti tveganju drugih članov verige. Pomembnejše odkritje je, da obstaja optimalna raven zmanjšanja emisij ogljika in dobička pri skupnem zmanjševanju emisij. Raziskava nudi vpogled v mehanizem delovanja nizkoogljične dobavne verige in članom dobavne verige ponudi napotke za cenovno in naložbeno strategijo zmanjševanja emisij.

(c) 2018 CPE, University of Maribor. All rights reserved.

\begin{tabular}{l} 
P O D A T K I O Č L A N K U \\
\hline Ključne besede: \\
Dobavna veriga; \\
Trgovanje z emisijami; \\
Emisije ogljika; \\
Analiza s teorijo iger; \\
Model srednje variance \\
*Kontaktna oseba: \\
feigemse@gmail.com \\
(Zhang, X.) \\
qinpeng@heuet.edu.cn \\
(Wang, Q.P.) \\
chenglinhu8@gmail.com \\
(Hu, C.L.) \\
Zgodovina članka: \\
Prejet 21. januarja 2018 \\
Popravljen 25. avgusta 2018 \\
Sprejet 7. septembra 2018
\end{tabular}

